\title{
The Impact of Agricultural Extension Service in Improving Vegetable Production in the West Coast Region of the Gambia
}

\author{
Lamin K M Fatty (Corresponding author) \\ Department of Sociology, Faculty of Social Sciences, Centre for Food Technology and \\ Research (CEFTER), Benue state University \\ Makurdi- Nigeria. Email: 1kmfatty@utg.edu.gm
}

Prof. Idu Ogbe Ode

Department of Sociology, Faculty of Social Sciences, Benue state University

Makurdi- Nigeria.

Received: May 2, 2016

doi:10.5296/jas.v6i1.12559
Accepted: May 16, 2016

URL: https://doi.org/10.5296/jas.v6i1.12559

\begin{abstract}
The study attempts to look at the role of Agricultural Extension Services in the improvement of vegetable production. Six vegetables schemes in Western Region of the Gambia for agricultural extension support and non- agricultural extension services support schemes were selected. Simple random sampling technique was employed to select sixty women producers for all the six garden schemes and three Agricultural Extension Agents. Majority of the respondents highlighted inadequate water/irrigation facilities, high cost of farm inputs/implements and, pests and diseases as the major constraints to production especially the non- vegetable support schemes. Occasional glut of vegetables in the market, in adequate transport, inadequate storage facilities and limited marketing outlets were marketing constraints which have adversely affected their production and income level. The authorities and Ministry of Agriculture should double efforts to enhance the number and capacity of Agricultural Extension Services for the successful dissemination of production technologies to non- vegetable support schemes, so that production and income can be improved.
\end{abstract}

Keywords: Vegetable production, improvement, extension workers, The Gambia 


\section{Macrothink}

\section{Introduction}

\subsection{Background}

Over $75 \%$ of the labour force in the Gambia is engaged in farming. Agriculture continues to be the prime mover of the Gambia economy, contributing between $25-30 \%$ of the country's Gross Domestic product (GDP) and generating almost $40 \%$ of the country's total export earnings (DOP, 2003). The agricultural sector in the Gambia is the main provider of food and income for most of the population, particularly the rural households whose livelihood system are characterized by the production of crops such as rice, upland cereals, horticultural and groundnut for food and income generation. It is mainly rain fed, largely fragmented in to small size holdings, and characterized by low input, resulting in low outputs. Only about $60 \%$ of the arable land is being cultivated. There is a huge scope for improving and increasing productivity and production by increasing output per unit area and also increasing the area under cultivation. A purely commercial farming (with the exception of few horticultural farms in the Western Region) is not a prominent feature of Gambian agriculture. The general configuration is one in which men have almost exclusive control of production of groundnut and women work in the swamps for the production of rice (Webb, 1992). However, this trend is now changing as both men and women are engaged in the rice and vegetable production due to the high economic returns realised. The farming system is singular in that there is little interaction between the farming activities carried out by men and women. Two separate farming systems operate in parallel; lowland rice and vegetable crops for women and upland coarse grains and groundnut production for men. Hoes and machetes are generally the only tools used for crop production husbandry by men and women. Crop and livestock husbandry practices are mainly traditional and largely influence by social norms little purchase of inputs and resulting in limited soil and water conservation measures.

\subsection{Problem Statement}

A great deal of efforts have been made by agricultural extension to ensure high and improved productivity and production of vegetables but little have been achieved to meet the national objectives of improved household food security and improved income particularly for the participants which are largely women farmers. Despite the intervention in the last few decades by government and development partners in the horticultural sector, vegetable production is still largely characterized by low input use, low output, inadequate storage facilities?, inadequate marketing outlets and lack of market information. Seasonality of vegetable supply with acute gluts in the local markets during peak harvest and acute scarcity due to seasonality and poor postharvest handling techniques have bedeviled agriculture production in the Gambia.. 


\subsection{Justification /Significant}

Vegetable production is one of the most important activities in the agricultural production system, with considerable comparative advantage and enormous potential for agricultural diversification. Increase in export and enhanced food security could substantially contribute to the country's economy and more so if the applications of appropriate agricultural production practices are adhered efficiently. Vegetable production has been expanding fast both for domestic consumption and export. This is because agricultural extension has given impetus to vegetable production in its effort to diversify the agricultural base and increasing farmer's income, improving their standard of living as well as their nutritional standard. Vegetable production is as always been an integral part of Western Region farming system, especially for women. In addition, , good road network and a more developed market for vegetable products are available.

The cultivation of vegetables has become a very important agricultural enterprise for women in the Western Region. This has been encouraged by low returns from cash crop production such as groundnuts and the continuous economic decline in real terms. It is estimated that a total of $50-60$ hectares of potential land area are suitable for vegetable production but more than $10 \%$ is currently cultivated (MOA, 1998). Producers are mainly small-scale individuals (with less than 1 hectare of land) and communal schemes (mainly of women with more than 5 hectares).

It is clear that there is a growing dependency on female income derived mainly from small-scale and communal vegetable gardening. Over the past few years, there has been a rapid proliferation of vegetable gardens throughout the Western Region with women constituting over $60 \%$ of growers. Although a large number of Peri-urban women are involved in vegetable production in which they are not getting a good deal from their produce due mainly to inadequate market outlet, weak bargaining power, sustainable practices, and farmer organization and processing and preservation facilities.

A major obstacle to full maximization of vegetable production also relates to the importation of cheap products to the disadvantage of the small scale producers. It has been observed that cheap imports of onions, Irish potatoes as well as other finished products are affecting the potential of local producers and wider regional marketing of local produce. It would be difficult for local products to compete with imported products unless considerable and real progress is made to develop national capacity to produce quality, processed and marketed locally produce vegetables at guaranteed supply. The existing agricultural policies should be applied in order to protect the local producers. The agricultural extension sector is one of the principal driving forces for the development of vegetable production and also an integral part of agricultural development in the Gambia. Notwithstanding, the agricultural research institute, NGOs and the private associations have long been pro-active for improved agricultural production and as a result, vegetable production has expanded in the past decade. It includes heterogeneous producers ranging from small indigenous communal and individual farms which later transformed to large commercialized producers and cooperatives with particular reference to vegetable production (Nagarajan et al; 1999). 


\section{Mll Macrothink}

\subsection{Objective of Study}

The main aim of the research was to gather adequate relevant facts about the role of agricultural extension in the improvement of vegetable production in the Western Region of the Gambia. It will specially look at agricultural extension intervention activities and its influence in vegetable production.

The following specific objectives were set for the study:-

1. To assess the role of agricultural extension workers in the improvement of vegetable

2. To assess the constraints confronting vegetable producers

3. To suggest possible solutions to improve vegetable production

\section{Literature Review}

\subsection{Definition}

Agricultural extension has been defined differently by different people. Various authors do not agreed on a standard definition simply because of the way it is organised in different forms to accomplish different objectives. Some of the definitions are outline below as follows: 'Agricultural extension can be defined as the provision of knowledge and skills necessary for farmers to be able to adopt and apply more efficient crop and animal production methods to improved their productivity and living standard' (Brunner, and Hsin PAO Yang, 1949). Agricultural extension is an educational process which has its goal to communicate useful information to people, helping them to learn how to use it to build a better life for themselves, their families and communities (Maunder, 1973). Agricultural extension "offers technical advice on agriculture to farmers and also supplies them with the necessary inputs and services to support their agricultural production. It produces information to farmers and passes the new idea developed by agricultural research station" (Oakley and Garforth, 1985). FAO defined agricultural extension as "an informal out of school" educational services for training and influencing farmers and their families to adopt improved practices in crop and livestock production, management, conservation and marketing" (Moris, 1991). Agricultural extension is a service or system which assists farm people through educational procedures in improving farming methods and techniques, increasing production efficiency, income, bettering their standard of living and lifting social standards (Adams, 1982). Despite the conceptual difference in the definition of Agricultural Extension in terms of communication of information and advice which are common to all definitions studied, we defined agricultural extension as an educational process and communication directed towards helping farmers to identify and analyse their production and marketing problems in order to become aware of the opportunities for improvement. 


\subsection{Scope and Paradigms of Agricultural Extension}

Agricultural extension is an effective two-way communication. Therefore the effectiveness of communication to take place, it is best to include individual/group farmer and small scale farming families in the process of directed change to evolve as a response to the crisis which agriculture faces in developing countries.

Agricultural extension is a prerequisite for widespread and sustained agricultural development. Thus an effective Agricultural extension service is needed to explain new technology to farmers for adoption of improved production practices in order to increase their production and income. Agricultural extension in agricultural development is largely catalytic and therefore often difficult to quantify. Although some of the results of the extension services remain unconvincing in many cases, the actual function of extension which is the dissemination of knowledge that is necessary for improving agricultural productivity remains essential because this improvement is an ongoing process, without any time constraints (Benor, 1984)

As it is clearly stated in the rural development strategy, in order to make agricultural development sustainable and thereby improve production and productivity, the approach in agricultural extension services delivery should take into account of agro-ecology, diversification and specialization of products, market orientation and improved quality of Agricultural extension agents and optimum use of resources. It is highly recommended that agricultural extension programmes should always be continuously reviewed so as to incorporate necessary changes (Buckland \& Peter Graham, 1980). Agricultural extension has a vital role in ensuring that the agro-economic and social environment of farmers and day-to-day production problems they face are appreciated by research. It is agricultural extension, however, that help farmers to take advantage of research findings and technological advancements quickly adjust to seasonal and economic conditions and effectively use support service to increase their production and income. In availability of agricultural extension guidance, farmers often are unable fully to exploit the opportunities available to them. According to Swanson (1981), agricultural extension can be described both in terms of how communication takes place and why it takes place. It is not always a matter of paternalistic systems is not persuasive nor the participatory projects are necessarily educational.

\subsection{Organisation and Development of Agricultural Extension Service in the Gambia}

The organisation of agricultural extension service in the Gambia was in the context of the World Bank, IMF supported structural adjustment programme which took place in the late 1970s to early 1980 (Cole, 1982). The most distinguished feature for the agricultural sector was the re-organisation of the extension services which include the introduction of Training and Visit System (T\&V System), coupled with the massive retrenchment of overstaff extension services. According to Cole (1982), there were 710 staff including 505 field staff and in 1981-1989, 215 staff including 170 field staff were recorded, (FAO, 1993). Since then, a series of developments have transpired to improve both technical and institutional capacity and serve the major developments as outline below:- 


\subsubsection{Decentralization of Agricultural Extension Service Administration:}

The activities of the department of agriculture were formally centralized in Yundum, Western Region, in which activities were accessible to a relatively much fewer farmers.

\subsubsection{Establishment of Units and Support Services:}

Training and specialization has made the department of agricultural extension more versatile and opportune. The setting up of technical units and support services is therefore, in response to varying extension needs. The primary objectives for setting up the units are to train and backstop the field level extension agents with specialized knowledge and skills.

2.3.3. The technical units and support services within the department of agricultural services (DAS) are:

Agricultural Communication Unit (ACU), Soils and Water Management Unit (SWMU), Agricultural Pest Management Unit (APMU), Horticulture Unit, Food and Nutrition Unit (FNU), Agricultural Input Office (AIO), Monitoring and Evaluation Unit (M\&E), and Agricultural Engineering Unit

\subsubsection{Systematic Training of Demonstrators to Village Extension Workers:}

Technical training of demonstrators before their deployment to the field by the department was inadequate. The training of demonstrators' cadre gives rise to what is today known in the Gambia as "Village Extension Worker (VEW). A systematic training has considerably improved staff quality and consequently the quality of services offered to farmers. The managers of village extension worker's station are graduates holding certificate in General Agriculture whereas the managers of District extension centre's (DEC) are District extension supervisors (DES) who are graduates of Higher Diploma in Agriculture; while divisional agricultural centres and units are managed by graduates and postgraduates.

\subsubsection{The Shifting of Ox-Ploughing Schools to District Extension Centres:}

The transformation of ox-ploughing schools to DEC's has resulted to a modern extension activities in crop and livestock production as well as protection principles where extension workers can acquire in-service training skills and apply the skills for the benefit of farmers. In the process of re-organising agricultural extension services, the Gambia experimented various extension systems and this was because there was the need to re-organise the extension services in order to make it more professional, effective and responsive to the needs of the clientele. From that onset, agricultural extension was given the mandate in its operation which aims to increase the knowledge and skills of farmers through the dissemination of improve agricultural technologies that focus mainly on crop and livestock improvement, human resource development and a collaborative programme with research and other departments, NGOs and development partners. In response to the vision 2020 agricultural objectives and the fact that vegetable sub-sector plays a pivotal role in the economic development of the Gambia, agricultural extension effort was focused towards more impact oriented strategies in attaining food security and thus alleviating poverty (DAS Profile of All events, 1994 - 2001) The agricultural extension agenda continues to focus on the use of 
improved varieties, soil fertility maintenance/conservation, effective water management techniques, processing and preservation technologies, and integrated pests \& disease management (IPM)

\subsection{Development of Vegetable Production in Western Region and Its Challenges}

The cultivation of vegetable crops has always been at the core of Western Region agricultural farming far back in the pre-colonial days (DOP report 1998). Vegetable production has been traditionally grown by female farmers in backyard gardens; in small holding and plots on an individual basis which is mainly limited to the cool / long dry season (October - May) for home consumption and sale of surpluses in the local markets and still continue in the same method. However, wet season production are improving through a combination of the introduction of suitable varieties coupled with the specialization of some growers in year round production because of its superior income earning potential. Many of the vegetables that are nowadays grown in the garden in the Western Region are not indigenous.

Vegetable production in Western Region is limited by farmer's lack of capital available for investment and improvement. The most critical environmental factor affecting vegetable production is the shortage of water, since vegetable is largely confined during the dry season and good production is only possible with reliable irrigation as well as the application of effective technical advice from agricultural extension. Western Region has the highest level of vegetable production involving $60 \%$ female farmers in which $42-89 \%$ sold over half of their produce at the local markets (Peri-urban Horticulture and Livestock Development Project annual report, (PHLDP), 2000).

Despite the much improvement of vegetable production in the region, several factors continue to limit the progress. Vegetable production in Western Region is dominated by three categories of producers.

These are those whose vegetable farms vary in size from 5ha to 50ha and utilize modern irrigation technology. Examples of such farms are Radville and Kharafi vegetable farms. These types of vegetable farms are producing mainly for the export markets and the hotel industries. About 25 of such farms use to operate in the peri-urban area, but only $6-10$ farms are now operating due to factors such as lack of capital investment and high running cost. By 1990, a total of 827ha of land was under large scale horticultural production, out of which a great proportion was devoted to vegetable production, (NARSGam, 1997).

The small back yard and private gardens such as Gambia are good and the horticultural enterprise limited vegetable garden generally have farms below 5 ha and utilize intensive labour techniques to produce their vegetable crops. Their production is mainly concerned for supplying local markets and hotels. A significant portion of their produce is also used for home consumption. About 500ha is estimated to be under this category (Concern Universal, 2000).

These garden schemes are operated by groups of women some of which are Banjulunding, Sukuta, Lamin, Kembujeh, Kampama farabulo and Serekundanding communal garden schemes. The area for cultivation per woman is small plots and production is always on a 
small scale in some areas, but in other areas, production is significant and used as part of their produce as consumption and some for sale at the local markets as well as the hotels. At other times, these communal village garden schemes will be contracted by the large scale vegetable farms and will be producing for them at a fixed price (PHLDP, 2000). Communal village garden schemes are now well established in western region, covering a total area of over 1000ha and providing farming opportunitiesfor over 22,000 growers, (DOSA, 1998).

\subsection{The Influence of Agricultural Extension in Vegetable Production}

During the last decades, vegetable production has generally been seen by agricultural extension services as an off-season activity but since the introduction of the economic recovery programme, the subsector has expanded considerably. Vegetable production in Western Region has played a key role in agricultural extension services activities which resulted in rapid trend in the expansion of vegetable production. There is a strong felt need to augment the knowledge and production technologies of agricultural extension workers in vegetable production, post harvest techniques and marketing of produce to enhance the efficiency of technology transfer to the climate. This will contribute to bridge the present gap of vegetable produce shortage within the region.

Encouragement by agricultural extension services and other development partners during the recent years has led to the establishment of network of growing of mixed vegetable varieties in most communal garden schemes. Equally, women growers are playing an increase role in the overall pattern of vegetable production expansion. Thus many growers are keen to expand or establish vegetable small holding plots. Currently agricultural extension places a great emphasis on the diversification of vegetable production. Agricultural extension has reiterated the development of a strong vegetable sub-sector that will help to close the food gap as well as improving the foreign exchange earning of the country, self-reliance and nutritional status of the primary producers, particularly women farmers and children. The intervention of agricultural extension services and other development partners over the years has led to increase in the number of people who are engage in vegetable production particularly male growers and also the area under cultivation,

\section{Methodology}

\subsection{Scope of the Study}

To achieve the objectives of the study, the role of agricultural extension in vegetable production in six selected sites of Western region, namely, Banjulinding, Sukuta and Lamin horticultural gardens were assessed as the Agricultural extension services support schemes and Kembujeh, Kampama Farabulo and Serekundading Women's horticultural gardens as the non-Agricultural extension services support schemes. The sample size consisted of vegetable growers and extension officers in the six production sites. Random samples of 60 vegetable growers (farmers) and three extension personnel were randomly selected from the population in the areas for data collection. The sampling units for each of the groups were the individuals and simple random sampling techniques were used. A set of questionnaires was developed separately for each of the vegetable growers and extension personnel. The 


\section{Macrothink}

Journal of Agricultural Studies

ISSN 2166-0379

2018, Vol. 6, No. 1

questionnaires were constructed by making references to two different sources of information - the improvement of vegetable production and opinions from experts. The improvement of vegetable production was measured by analyzing the following:- Level of service delivery by extension personnel, use of technological innovations / adoption rate, farmers receptiveness to new production technologies, vegetable production constraints, increase output / unit area, timely availability of resources (inputs and implements), assistance available to vegetable growers, source of production inputs, and increase in income. Each questionnaire set was unevenly divided into four sub-sections. The first section was the background information about the respondent. The second section describes the respondent's socio economic profile/demographic information and finally the third and fourth sub-sections focuses on the production trend and constraints. The questionnaires were pretested for any inconsistency and undefined terms or interpretation of terminologies in the subject matter. Two sets of questionnaires were administered each to the producer respondents and extension personnel. The questionnaires were administered anonymously to the individual respondents by the researcher with the help of extension personnel attached to the selected vegetable schemes.

\subsection{Data Analysis}

Data were analysed by using statistical package for social sciences (SPSS) which facilitated the generation of frequency count tables for the presentation and interpretation of results as well as discussion and reporting of the study.

\section{Results and Discussion}

\subsection{Analysis of Yields and Cultivated Areas in Agricultural Extension Services Support} Schemes in three Selected Areas 2005 - 2008

Lettuce produced the highest total yields of 18.6t among the major crops grown in the Sukuta scheme with an average yields of $37.2 \mathrm{t} / \mathrm{ha}$, followed by cucumber which has a total yield of $18.30 \mathrm{t}$ with an average yields of $36.6 \mathrm{t} / \mathrm{ha}$ (Table 1). The lowest yielding crops were reddish, egg plants, cabbage and large pepper. Furthermore, considering the highest average yields, carrot and sweet potato had the highest compared to the major crops grown in the scheme. However, in this scheme crops such as onion and shallot were not grown during the wet season simply because of low quality performance of the varieties available. 


\section{Ml Macrothink}

Journal of Agricultural Studies

ISSN 2166-0379

2018, Vol. 6, No. 1

Table 1: Wet season vegetable crop yields produce in tons/ha in Sukuta women's horticultural garden from 2005-08

\begin{tabular}{lccc}
\hline Crop Type & Area Cultivated (ha) & $\begin{array}{c}\text { Total Yields produce } \\
\text { in (tons) }\end{array}$ & $\begin{array}{c}\text { Average Yields in } \\
\text { tons / ha }\end{array}$ \\
\hline Tomato & 0.50 & 16.20 & 32.40 \\
Egg Plant & 0.55 & 3.70 & 6.73 \\
Bitter Tomato & 0.50 & 7.70 & 15.40 \\
Lettuce & 0.50 & 18.60 & 37.20 \\
Cabbage & 0.55 & 3.70 & 6.73 \\
Okra & 1.00 & 14.50 & 14.50 \\
Cucumber & 0.50 & 18.30 & 36.60 \\
Carrot & 0.01 & 0.80 & 80.00 \\
Sorrel & 0.55 & 6.80 & 12.36 \\
Radish & 0.70 & 3.10 & 4.43 \\
Sweet potato & 0.01 & 0.70 & 70.00 \\
Sweet Pepper & 0.75 & 8.60 & 11.47 \\
Large Pepper & 0.55 & 3.50 & 6.36 \\
Hot Pepper & 0.50 & 10.90 & 21.80 \\
Chilli Pepper & 0.30 & 4.50 & 15.00 \\
\hline
\end{tabular}

Among the crops grown in Lamin scheme, tomato produced the highest total yields of 16.90 tons from 0.50 hectares with an average yields of 33.80t/ha (Table 2). The second highest was eggplant which had a total yield of $29.40 \mathrm{t} /$ ha from 1 ha with an average yields of $29.40 \mathrm{t} / \mathrm{ha}$. The lowest was large pepper which had a total yield of 1.40t/ha with average yields of 5.60t/ha. However, onion, sweet potato, shallot and chilli pepper were not grown in this scheme during the wet season, and this was due to the low performance of the varieties in the previous seasons.

Table 2: Wet season vegetable crop yields produce in tons/ha in Lamin women's horticultural garden from 2005-2008

\begin{tabular}{lccc}
\hline Crop Type & $\begin{array}{c}\text { Area Cultivated } \\
\text { (ha) }\end{array}$ & $\begin{array}{c}\text { Total Yields } \\
\text { produce in (tons) }\end{array}$ & Average Yields in tons / ha \\
\hline Tomato & 0.50 & 16.90 & 33.80 \\
Egg Plant & 1.00 & 29.40 & 29.40 \\
Bitter Tomato & 1.20 & 22.50 & 18.75 \\
Cabbage & 0.50 & 12.50 & 25.00 \\
Okra & 1.30 & 18.70 & 14.38 \\
Cucumber & 0.50 & 12.80 & 25.60 \\
Carrot & 0.05 & 1.10 & 22.00 \\
Sorrel & 0.55 & 7.70 & 14.00 \\
\hline
\end{tabular}




\begin{tabular}{lccc}
\hline Radish & 0.50 & 8.90 & 17.80 \\
Sweet Pepper & 0.06 & 6.10 & 101.67 \\
Large Pepper & 0.25 & 1.40 & 5.60 \\
Hot Pepper & 0.50 & 12.50 & 25.00 \\
\hline
\end{tabular}

Bitter tomato had the highest total yields of $28.9 \mathrm{t}$ with an average yield of $20.64 \mathrm{t}$ from 0.25 hectares of cultivated area in the Banjulunding (Table 3). Tomato being the second largest yielding crop produced a total yield of $27.70 \mathrm{t}$ with average yields of $55.40 \mathrm{t}$ from $0.50 \mathrm{ha}$. The lowest yielding crop was carrot which had a total yield of 1.40 tons with an average of yields of $1.87 \mathrm{t}$ from 0.75 ha of land. However, crops such as lettuce, onion, sweet potato, shallot and chilli pepper were not popular crops grown in this scheme during the wet season.

Table 3: Wet season vegetable crop yields produce in tons/ha in Banjulunding women's horticultural garden from 2005-2008

\begin{tabular}{lccc}
\hline Crop Type & Area Cultivated (Ha) & $\begin{array}{l}\text { Total Yields produce in } \\
\text { (tons) }\end{array}$ & $\begin{array}{l}\text { Average Yields in } \\
\text { tons/ha }\end{array}$ \\
\hline Tomato & 0.50 & 27.70 & 55.40 \\
Egg Plant & 0.75 & 23.10 & 30.80 \\
Bitter Tomato & 1.40 & 28.9 & 20.64 \\
Lettuce & 0.00 & 0.00 & 0.00 \\
Cabbage & 0.5 & 13.40 & 26.80 \\
Onion & 0.00 & 0.00 & 0.00 \\
Okra & 1.20 & 13.50 & 11.25 \\
Cucumber & 0.75 & 10.30 & 13.73 \\
Carrot & 0.75 & 1.40 & 1.87 \\
Sorrel & 0.70 & 4.20 & 6.00 \\
Radish & 0.55 & 0.40 & 0.43 \\
Sweet Pepper & 0.70 & 4.30 & 6.14 \\
Large Pepper & 0.25 & 2.80 & 11.20 \\
Hot Pepper & 0.25 & 26.70 & 106.80 \\
\hline
\end{tabular}

Lettuce produced the highest total yields of $73.80 \mathrm{t}$ from $0.45 \mathrm{ha}$ of land with average yield of 164 t/ha in the Sukuta scheme in the dry season (Table 4). Tomato which was the second highest produced total yield of 24.30t from 1.45 ha with an average yields of $16.76 \mathrm{t} / \mathrm{ha}$. The lowest yielding crop was shallot with a total of $0.40 \mathrm{t}$ from 0.08 ha and average yields of $5 \mathrm{t} / \mathrm{ha}$. 
Table 4: Dry season vegetable crop yields produce in tons/ha in Sukuta women's horticultural garden 2005-2008

\begin{tabular}{|c|c|c|c|}
\hline Crop Type & Area Cultivated (ha) & $\begin{array}{l}\text { Total Yields produce } \\
\text { in (tons) }\end{array}$ & Average Yields in tons / ha \\
\hline Tomato & 1.45 & 24.30 & 16.76 \\
\hline Egg Plant & 0.75 & 6.50 & 8.67 \\
\hline Bitter Tomato & 0.02 & 8.10 & 405.00 \\
\hline Lettuce & 0.45 & 73.80 & 164.00 \\
\hline Onion & 1.25 & 10.10 & 8.08 \\
\hline Cabbage & 0.06 & 23.90 & 398.33 \\
\hline Okra & 0.75 & 4.90 & 6.53 \\
\hline Cucumber & 0.02 & 10.3 & 515.00 \\
\hline Carrot & 0.03 & 2.00 & 66.67 \\
\hline Sorrel & 0.25 & 2.20 & 8.80 \\
\hline Radish & 0.03 & 1.30 & 43.33 \\
\hline Shallot & 0.08 & 0.40 & 5.00 \\
\hline Sweet Pepper & 0.02 & 1.10 & 55.00 \\
\hline Large Pepper & 0.75 & 1.40 & 1.87 \\
\hline Hot Pepper & 0.6 & 2.50 & 4.17 \\
\hline Chilli Pepper & 0.3 & 0.50 & 1.67 \\
\hline
\end{tabular}

Tomato had the highest cultivated area of 10ha of land, followed by onion an area of 1.50ha (Table 5). However, crops like cucumber, sweet potato and shallot were not grown in this scheme simply because of low performance of yields obtained from the previous seasons. As far as yields were are concerned, onion produced the highest total yields of $128.30 \mathrm{t}$ with an average of $85.53 \mathrm{t} / \mathrm{ha}$ followed by tomato with total yield and average yields of 19.70t Radish, the lowest produced crop had total yield of $0.40 \mathrm{t}$ and average yield of $0.73 \mathrm{t} / \mathrm{ha}$ from $0.73 \mathrm{ha}$.

Table 5: Dry season vegetable crop yields produce in tons/ha in Lamin women's vegetable garden in 2005-2008

\begin{tabular}{lccc}
\hline Crop Type & Area Cultivated (ha) & $\begin{array}{l}\text { Total Yields produce } \\
\text { in (tons) }\end{array}$ & $\begin{array}{l}\text { Average Yields in tons / } \\
\text { ha }\end{array}$ \\
\hline Tomato & 10.00 & 19.70 & 19.70 \\
Egg Plant & 1.30 & 12.50 & 9.62 \\
Bitter Tomato & 1.40 & 14.70 & 10.50 \\
Lettuce & 0.25 & 3.00 & 12.00 \\
Onion & 1.50 & 128.30 & 85.53 \\
Cabbage & 0.04 & 10.10 & 252.50 \\
Okra & 1.30 & 16.10 & 12.38 \\
Sorrel & 0.25 & 7.00 & 28.00 \\
Radish & 0.55 & 0.40 & 0.73
\end{tabular}


For the Banjulunding scheme in the dry season, tomato produced the highest total yields of $76.80 \mathrm{t}$ from $1.50 \mathrm{ha}$ of cultivated area, with average yields of 51.20t/ha (Table 6). Onion has the second highest produced crop with total yield of 19.40t an area of 1.50ha with an average yield of 12.9t/ha. The lowest yielding crop was radish which has total yields of $0.30 \mathrm{t}$ from $0.70 \mathrm{ha}$ and an average yield of $0.43 \mathrm{t} / \mathrm{ha}$. However, sweet potato and shallot were not grown in this scheme during the dry season production.

Table 6: Dry season vegetable crop yields produced in tons/ha in Banjulunding garden from 2005-2008

\begin{tabular}{lccc}
\hline Crop Type & Area Cultivated (ha) & $\begin{array}{c}\text { Total } \\
\text { produce in (tons) }\end{array}$ & $\begin{array}{c}\text { Yields } \\
\text { Average } \\
\text { tons /ha }\end{array}$ \\
\hline Tomato & 1.50 & 76.80 & 51.20 \\
Egg Plant & 1.20 & 11.60 & 9.67 \\
Bitter Tomato & 1.40 & 10.00 & 7.14 \\
Lettuce & 0.75 & 6.50 & 8.67 \\
Onion & 1.50 & 19.40 & 12.93 \\
Cabbage & 1.20 & 15.70 & 13.08 \\
Okra & 0.01 & 7.50 & 7.50. \\
Cucumber & 1.20 & 4.50 & 3.75 \\
Carrot & 0.25 & 3.50 & 14.00 \\
Radish & 0.70 & 0.30 & 0.43 \\
Sweet Pepper & 0.55 & 1.00 & 1.82 \\
Large Pepper & 0.55 & 0.90 & 1.64 \\
Hot Pepper & 0.55 & 1.40 & 2.55 \\
\hline
\end{tabular}

A total of 60 respondents were interviewed on how and what resource constraints they face in vegetable production (Table 7). In Banjulunding women's horticultural garden, 20\% of the respondents mentioned that they have experienced garden tool, 25\% mention water supply facilities and $5 \%$ mention market outlets whereas $30 \%$ of the respondents experienced farm machineries and $10 \%$ of the respondents experienced pest and $10 \%$ of the respondents mention disease outbreak problems.

In Lamin women's horticultural garden $20 \%$ of the respondents indicated experiencing farm machineries, $20 \%$ mentioned garden tools, and $25 \%$ said water supply facilities and $15 \%$ 
mentioned marketing outlets. The $10 \%$ of the total respondents mentioned pest \& $10 \%$ mention diseases as major constraints.

In Sukuta women's horticultural garden, $50 \%$ of the respondents experienced input constraints whereas $10 \%$ mention disease outbreak problems, $10 \%$ mentioned constraints on garden tools, $10 \%$ mentioned water supply facilities and $10 \%$ of the respondent faced constraints on marketing outlet. In the same vein, $10 \%$ of the respondents have constraints on both farm machineries. Technical Mission is the main provider of assistance to all the schemes. Most of the type of assistance provided by these institutions are technical advice, inputs and implements in a continuous process and seasonally. Other support institutions that provide assistance to Sukuta and Lamin women's horticultural garden are Swedish Foundation and Fandona and women's Bureau respectively.

Table 7: Production/resource constraints at the various vegetable gardens

\begin{tabular}{|c|c|c|c|c|c|c|c|c|c|c|c|c|c|c|c|}
\hline \multirow[t]{3}{*}{ Locations } & \multirow[t]{3}{*}{$\begin{array}{l}\text { No. of } \\
\text { responden } \\
\mathbf{t} \\
\text { interview }\end{array}$} & \multicolumn{2}{|c|}{ Inputs } & \multicolumn{2}{|c|}{$\begin{array}{l}\text { Garde } \\
\text { n Tools }\end{array}$} & \multicolumn{2}{|c|}{$\begin{array}{l}\text { Farm } \\
\text { Machi } \\
\text { neries }\end{array}$} & \multicolumn{2}{|c|}{$\begin{array}{l}\text { Water } \\
\text { supply }\end{array}$} & \multicolumn{2}{|c|}{$\begin{array}{l}\text { Disease } \\
\text { outbreak } \\
\text { problems }\end{array}$} & \multicolumn{2}{|c|}{$\begin{array}{l}\text { Pest } \\
\text { outbreak } \\
\text { problems }\end{array}$} & \multicolumn{2}{|c|}{$\begin{array}{l}\text { Marke } \\
\text { ting } \\
\text { constra } \\
\text { ints }\end{array}$} \\
\hline & & No & $\%$ & $\mathrm{~N}$ & $\%$ & $\mathrm{~N}$ & $\%$ & $\mathrm{~N}$ & $\%$ & No. & $\%$ & No. & $\%$ & $\mathrm{~N}$ & $\%$ \\
\hline & & & & o & & o. & & o & & & & & & o. & \\
\hline Banjulundin & 20 & 0 & 0 & 4 & 20 & 5 & 25 & 6 & 30 & 2 & 10 & 2 & 10 & 1 & 5 \\
\hline $\mathrm{g}$ Women's & & & & & & & & & & & & & & & \\
\hline Horticultura & & & & & & & & & & & & & & & \\
\hline 1 Garden & & & & & & & & & & & & & & & \\
\hline Lamin & 20 & 0 & 0 & 4 & 20 & 4 & 20 & 5 & 25 & 2 & 10 & 2 & 10 & 3 & 15 \\
\hline Women's & & & & & & & & & & & & & & & \\
\hline Horticultura & & & & & & & & & & & & & & & \\
\hline 1 Garden & & & & & & & & & & & & & & & \\
\hline Sukuta & 20 & 10 & 5 & 2 & 10 & 2 & 10 & 2 & 10 & 2 & 10 & 0 & 0 & 2 & 10 \\
\hline Women's & & & 0 & & & & & & & & & & & & \\
\hline Horticultura & & & & & & & & & & & & & & & \\
\hline 1 Garden & & & & & & & & & & & & & & & \\
\hline
\end{tabular}

As indicated in table 8, analysis shows that a total of 60 respondents were interviewed on the adoption of Agric Extension services production technologies by farmers. Results in Banjulunding \& Lamin women's horticultural garden shows that of the total respondents, $100 \%$ respondents adopts agric extension services production technologies whereas no respondents mentioned not adopting agric extension services on production technologies. Unlike in Sukuta women's horticultural garden, were results revealed that $80 \%$ of the respondents adopt agric extension services production technologies and $20 \%$ of the respondents indicated not adopting agric extension services production technologies 
Table 8: Percentage adoption of agricultural extension messages on production technologies by farmers

\begin{tabular}{lccr}
\hline \multicolumn{1}{c}{ Locations } & $\begin{array}{c}\text { Number of } \\
\text { respondents } \\
\text { interview }\end{array}$ & $\begin{array}{c}\text { *Percentage (\%) of } \\
\text { adoption }\end{array}$ & $\begin{array}{c}\text { *Percentage (\%) of not } \\
\text { adoption }\end{array}$ \\
\hline $\begin{array}{l}\text { Banjulunding Women's } \\
\text { Horticultural Garden }\end{array}$ & 20 & 100 & 0 \\
$\begin{array}{l}\text { Lamin Women's Horticultural } \\
\text { Garden }\end{array}$ & 20 & 100 & 0 \\
$\begin{array}{l}\text { Sukuta Women's Horticultural } \\
\text { Garden }\end{array}$ & 16 & 80 & 20 \\
\hline
\end{tabular}

* Percentage of farmers who adopt Agric extension service production technologies (crop spacing, protection, fertilizer application, weed management, staggering and post harvest techniques, and those who do not adopt the technologies)

In table 9, results revealed that a total of 60 respondents were interviewed on the frequency of visit by extension personnel in the three vegetable schemes. However results obtained from the three schemes shows that the entire respondents' in all the vegetable schemes agreed that frequency of extension personnel visits to the schemes is on a daily basis (20 times) each.

Table 9: Frequency of visit by extension personnel's in the vegetable schemes

\begin{tabular}{llcccc}
\hline Location & $\begin{array}{l}\text { No. of } \\
\text { respondents } \\
\text { interview }\end{array}$ & Daily & Fortnightly & Monthly & Bi-Monthly \\
\hline $\begin{array}{l}\text { Banjulunding Women's } \\
\text { Horticultural Garden }\end{array}$ & 20 & 20 & 0 & 0 & 0 \\
$\begin{array}{l}\text { Lamin Women's } \\
\text { Horticultural Garden }\end{array}$ & 20 & 20 & 0 & 0 & 0 \\
$\begin{array}{l}\text { Sukuta Women's } \\
\text { Horticultural Garden }\end{array}$ & 20 & 20 & 0 & 0 & 0 \\
\hline
\end{tabular}

Table 10 shows that a total of 60 respondents with an age distribution ranging from $0-69$ years were interviewed on methods used in vegetable production in the three schemes. In Banjulunding women's horticultural garden, result shows that $90 \%$ of the respondents ranging 30-69 years of age revealed that extension services methods are used in their scheme where as $10 \%$ of the respondents ranging from $60-69$ years agreed that both indigenous and agric extension services methods are used in their scheme. Results in Lamin women's 


\section{Macrothink}

horticultural garden shows that the $80 \%$ of the respondents within the age bracket of $30-69$ years of age agreed that Agric extension services methods are used in their scheme while $10 \%$ of the respondents ranging from $60-69$ years of age applies the indigenous methods of production and $10 \%$ respondents' ranging from 50 - 59 years shows that both methods are used in their scheme. As indicated in Sukuta women's horticultural garden, $70 \%$ of the respondents ranging from $40-69$ years of age show that agric extension services methods are used in their scheme, whereas 10\% ranging from 40-49 years of age mentioned indigenous methods and 20\% ranging 50-59 years said both methods are used in their scheme

Table 10 Age distribution and vegetable production methods used in the three schemes

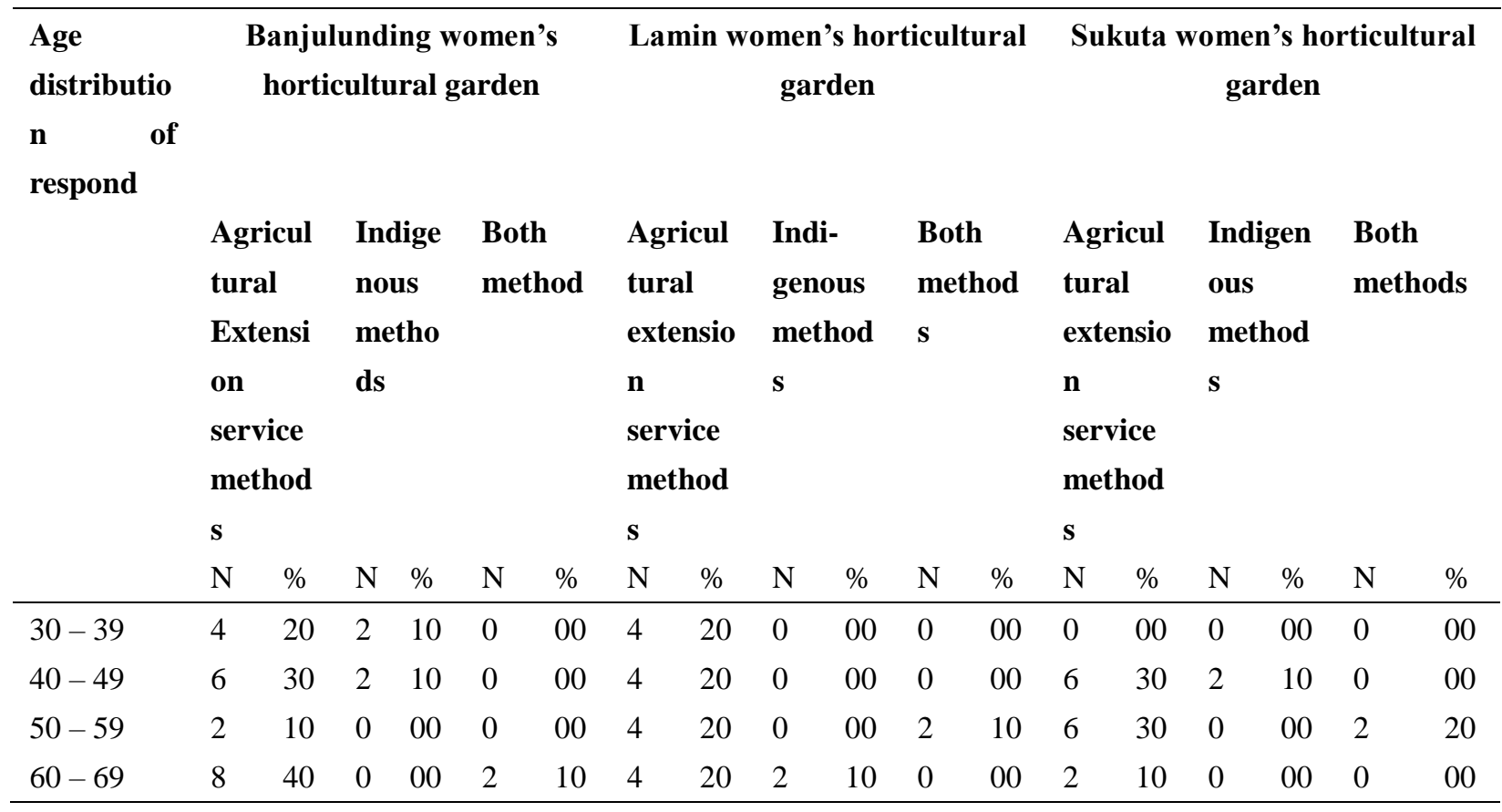

Results of table 11 shows that a total of 60 respondents were interviewed on vegetable producer's perception about Agric extension personnel. According to the different parameters used, $81.67 \%$ (49) respondents scored excellent as the highest, followed by $8.33 \%$ (5) respondents scoring very good and $10 \%$ (6) respondents scoring good.

In Banjulunding women's horticultural garden, all the $20(100 \%)$ respondents interviewed perceived Agric extension personnel as excellent service providers where as no respondent mentioned any of the other parameters. Unlike Lamin women's horticultural garden, $15(75 \%)$ respondents rated Agric extension personnel as excellent service providers, 3(15\%) respondents rated it as very good and $2(2 \%)$ respondents rated agricultural extension personnel perception as good. Results in Sukuta women's horticultural garden shows 14 (70\%) respondents perceived Agricultural extension personnel as excellent, 2 (10\%) respondent said very good and $4(20 \%)$ respondents mentioned good. 
Table 11 Perception of Vegetable producers about agricultural extension personnel

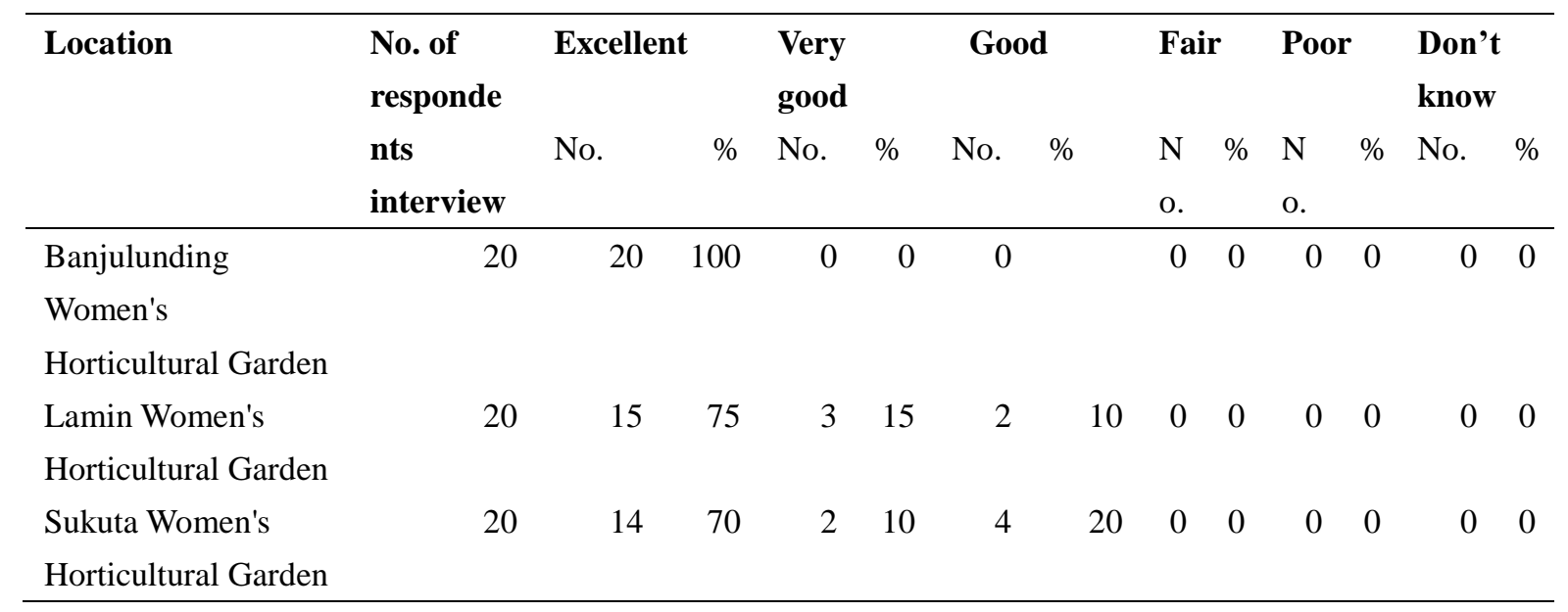

\section{Conclusion and Recommendation}

According to the majority of the respondents in the support schemes, the effect of agric extension services in vegetable production contributed immensely to the improvement of vegetable production through the use of technical advised(i.e. application of sound agronomic practice as indicated in table $10 \&$ table 11). Where as in the non support schemes, the lack of agricultural extension services support has affected vegetable production considerably.

Analysis has also revealed that, support schemes average yields during the dry \& wet season production has outstripped the non support schemes average yields. From the findings, major crops grown such as bitter tomato has the highest average yields in the support schemes during the dry season whereas it is the lowest in the non support schemes during the wet season as flagged in table 8 - 11. The high levels of bitter tomato average yields in the support schemes were attributed to application of sound agronomic practices, high yielding varieties, high production inputs and the used of irrigation facilities which enhanced productivity as they have been receiving support from Agricultural extension services, Taiwan Agricultural Technical mission and other NGOs, for several years (see table 8-9) .

In the case of seasonal yields performance, dry season yields performed better compare to wet season production. The reason for these significance differences of seasonal yields performance is due to the fact that crop varieties available in the schemes are cool season varieties and can do bitter during the dry season compare to wet season. The availability of these suitable crop varieties also influences the area put to cultivation during the dry season.

It is found that non support schemes producers encounter difficulties ranging from inadequate availability of production inputs, inadequate implements, insufficient water supply, lack of proper transportation and storage facilities, inadequate control measures on pest \& diseases etc. These constraints led to the reduction of vegetable production in the non support schemes as seen in table 8.

What is apparently clear in the study is that, almost, all the women producers in the support 
schemes appears to plant the same varieties and above all, follows no production planning so as to avoid glut or scarcity in the markets. Thus, with no proper storage facilities in place, the producers in the non-support schemes are usually force to supply their produce to middlemen before they perish or lost freshness, which leads to low prices of vegetables. The existing constraints in the non support schemes, when properly and adequately addressed could lead to the overall improvement of vegetable production in general and the living standards of women farmers, in particular, thereby enhancing their economic base for vegetable producers in the non support schemes.

\subsection{Recommendation}

Base on the findings of this study, the researcher concludes that, women producers in the non support schemes should access to Agric extension service as well as improve vegetable production technologies and other essential production inputs.

There is need also for an effective and efficient system of extension service sustenance at the vegetable production sites in the area and if possible country wide.

In addition to that, extension agents should have continuous and efficient training to be be provided to the production sites so as to continue given assistance to the women vegetable farmers.

\section{Acknowledgement}

The research is financed by my own with the assistance from my colleagues Professor Sidat Yaffa, and Mr. Mamma Sawaneh, University of The Gambia. Thanks also go to Mr. Sainey Keita, head School of Agricultural Sciences, my wives and children and entire students of the school for the support given me while undertaken the research.

\section{References}

Adams, M. E. (1982). Agricultural extension in developing countries, 1 - 54.

Adams, M. E. (1982). Agricultural Extension in Developing Countries. Longman Group Ltd. Singapore, 108.

Benor, D. \& Baxter, M. (1984). Agricultural Extension: The Training and Visit System World Major Agricultural Extension Providers in Tanzania 169 Bank, Washington, D.C.

Brunner, E., \& Hsin Pao Yang, E. (1949) Rural America and the Extension Service, Columbia University.

Buckland, J., \& Graham P. (1980). Agricultural administration (Research \& Extension) Network paper, $17-64$.

Cole, R. (1982). Agricultural Data for Decision Makers, 2023 South Federal Avenue Mason City, Iowa 50401-6726.

Danniel B., James Q., Harrision, \& Michael, B. (1984). Agricultural extension - The training and visit system, $2-63$. 


\section{Macrothink}

Journal of Agricultural Studies

ISSN 2166-0379

2018, Vol. 6, No. 1

Department of State for Agriculture. (1998). Development of small-scale Irrigation Facilities for Women Horticultural Producers.

DOP (Department of Planning). (2003). Statistical Yearbook on Gambian agriculture for the year 2002. Annual Report. Department of State for Agriculture.

Food and Agriculture Organization of the United Nations (1993). Improving agricultural extension, Rome.

Maunder, A. (1973). Agricultural Extension: A Reference Manual (1st Edition), FAO.

Ministry of Agriculture, (1998). Statistical yearbook of Gambian agriculture 1990.

Moris, J. (1991) Extension Alternatives in Tropical Africa. UK: Overseas Development Institute

Nagarajan, G. M., Richa, L., \& Graham, D. H. (1999). Exporting Fresh fruits and vegetables to Europe: Potential and constraints for Gambia producers. Economics and Sociology Occasional Paper No. 2166, Agency for International Development, Washington, D. C. 1-19

Oakley, P. and Garforth, C. (1985). Guide to Extension Training. Rome: Food and Agricultural Organization of the United Nations.

Peri - urban horticulture and livestock development project annual report (2000).

Sanyang, S. E., Te-chen, \& Kand wen-chi, H. (2009). The impact of Agricultural technology to women vegetable production and marking groups in the Gambia, in world journal of Agricultural Sciences (2): 169 - 179.

Sanyany, S. T. J. (2005). Status report on selected horticultural production schemes in Western region, $3-7$.

Swanson, B. (1981). "Improving Agricultural Extension: A Reference Manual (3rd Edition)" FAO.

Webb, P. (1992). "Impacts on division of labour and the role of women" in Policy issues for rice development in The Gambia, (by IFPRI \& PPMU), 25-32, Washington DC. 


\section{Macrothink}

Journal of Agricultural Studies

ISSN 2166-0379

\section{Copyright Disclaimer}

Copyright for this article is retained by the author(s), with first publication rights granted to the journal.

This is an open-access article distributed under the terms and conditions of the Creative Commons Attribution license (http://creativecommons.org/licenses/by/4.0/). 